\title{
Can Explicit Written Corrective Feedback Develop Grammatical and Lexical Accuracy of Saudi EFL Learners?
}

\author{
Nahla Al-Hazzani, Sultan Altalhab* \\ College of Education, King Saud University, Riyadh, Saudi Arabia \\ Corresponding author: Sultan Altalhab, E-mail: saltalhab@ksu.edu.sa
}

\section{ARTICLE INFO}

Article history

Received: July 02, 2018

Accepted: October 29, 2018

Published: October 31, 2018

Volume: 6 Issue: 4

Conflicts of interest: None

Funding: None

\begin{abstract}
Saudi students encounter many problems in writing skill as several studies revealed (e.g. Alhazmi, 2006; Alsamdani, 2010). Providing effective and useful feedback may help to overcome these challenges. Therefore, this study examines the effect of teachers' written corrective feedback on female Saudi EFL students' written essays and to what extent it affects students' written grammatical and lexical accuracy. The sample comprises 50 foundation level students, across two groups: an experimental group $(n=29)$ and a control group $(n=21)$. Data were gathered over a 10 -week period using a pre-/post-test/delayed post-test design for comparable groups. The findings show that although many errors were made in the writing performances, the students in the experimental group had significantly better achievements than the students in the control group on the measure. The results lend support to the efficiency of teachers' written corrective feedback, showing it has a significant positive effect on the participants' grammatical and lexical accuracy.
\end{abstract}

Key words: Feedback, Correction, Accuracy, Writing

\section{INTRODUCTION}

Providing feedback is an extremely valuable tool for indicating whether students are going in the right direction with their work or not. In other words, it reinforces learners' understanding and corrects them through the use of various methods. Providing feedback for learners' writing helps them develop EFL writing abilities as they attempt to revise a written assignment (Williams \& Jasmine, 2003). If done correctly, positive and effective written feedback will encourage the learner to continue developing their skills and may studies have shown it to be effective (Ferris, 2003). Although giving feedback is a complex skill, it is also a task that one needs to perform constantly in order to make learners aware of their level and how to continue in terms of expectations and goals.

Feedback is an essential part of education and certainly of any English language-writing course. Ur (1996, p. 242) defined feedback as "information that is given to the learner about his or her performance of the learning task, usually with the objective of improving their performance." In the field of education and in ESL classrooms specifically, written corrective feedback is a common and frequent practice preferred by teachers (Ferris, 2007). Here, a student receives either formal or informal feedback on his performance of various tasks by a teacher or peer. Bitchener and Storch (2016) defined written corrective feedback as a written response to a linguistic error that has been made in the writing of a text by a second language (L2) learner. Today, written corrective feedback, an instructional strategy widely used in ESL classrooms, is used to improve students' writing (Ferris, 1999).

In error correction, the effectiveness of written corrective feedback is crucial (Hyland \& Hyland, 2006). However, the question that remains is whether it is useful for the learner's improvement of their writing skills or not. This is the main interest of many researchers (e.g. Chandler, 2003) and remains an ongoing debate. Thus, many recent studies (Bitchener \& Knoch, 2010a; Bitchener, 2008; Sheen, 2007) have examined if receiving and processing written corrective feedback can help in language learning; these have included the comparison and analysis of learners' performance in terms of writing compositions. Therefore, the current study aims to investigate the following research questions:

1. Is explicit written corrective feedback effective for Saudi EFL students' writing?

2. To what extent does the use of explicit written corrective feedback affect Saudi EFL students' written grammatical and lexical accuracy?

\section{LITERATURE REVIEW}

For decades now, the efficiency of error correction or written corrective feedback has been a controversial and ongoing debate. EFL learners' errors are significant for the understanding of the processes of Second Language Acquisition (Candling, 2001). 
Many studies in the correction of second language errors suggest that teacher's corrective feedback can help develop learner's accuracy in terms of writing (Ferris, 2004). In second language learning, corrective feedback is considered an area of interest for both writing instructors and composition theorists (Ferris, 1999). Additionally, Ferris and Roberts (2001) and Hyland and Hyland (2006) stated that teacher feedback is essential to the improvement of second language skills including writing. Truscott (1996); however, asserted that error correction is a waste of both the teacher's and the student's time and that learners should instead be practicing writing. It is also argued that it has little or no effect on the progress of learners (Doff, 1988), while potentially leading to learners' anxiety and stress (Truscott, 1996).

Making errors in an ESL classroom is normal for learners and those errors should be treated (Ferris, 2002). Moreover, a teacher's explicit corrective feedback helps ESL students with their writing accuracy (Bitchener et al., 2005). Students who received written corrective feedback then revised their writing are seen to improve over time and outperform those who did not (Ferris \& Roberts, 2001; Chandler 2003). Moreover, some types of feedback encourage learners to solve problems and guide their own writing (Ferris, 2004; Bitchener \& Knoch, 2010b; Bitchener \& Ferris, 2012) while other types endorse reflection on one's knowledge (Bitchener \& Ferris, 2012).

Contrary to many researchers, Truscott (2007:271) claimed that written corrective feedback is a 'clear and dramatic failure', stating that grammar or error correction has no place in any writing course and should be abandoned. He argued that learners are unwilling to accept their teacher's error corrections and either continue to write as they did before or avoid the conflictive error in future writing. On the other hand, Ferris (1999) disputed this claim, arguing that it was not possible to dismiss correction in general as it depended on the quality of the correction. In other words, error correction can improve students' future writings if it was combined with the right methodology. A growing body of study suggests that written corrective feedback can improve writing accuracy, according to the context.

Several recent studies have been conducted on the different kinds of corrective feedback (Khoshsima \& Ma'Farid, 2012; Hashemnezhad \& Mohammadnejad, 2012; Ferris \& Roberts, 2001; Alharbi, 2016). These studies show positive evidence of the effectiveness of corrective feedback over no feedback. A study by Khoshsima and Ma'Farid (2012) investigated the effectiveness of corrective feedback (both explicit and implicit) in EFL writing accuracy. Two groups were selected, one receiving explicit corrective feedback and the other receiving implicit corrective feedback. The results showed that written corrective feedback can lead to writing improvement. Moreover, in another study by Hashemnezhad and Mohammadnejad (2012), learners were required to write a 250- word composition in every class, and corrective feedback (direct and indirect) was provided. Learners improved by applying the feedback to their writing. They concluded similar results at the end of their study, finding that learners could detect errors and that direct feedback was more helpful to them than indirect feedback. Furthermore, Ferris and Roberts (2001) conducted a study on 72 ESL university students to find the effects of several given self-editing tasks: errors marked with codes, errors underlined but not marked, and no feedback. The study reported that students receiving feedback on their compositions excelled more than the participants who did not. Alharbi's (2016) 10-week study at King Saud university, also investigated the effect of written corrective feedback on the university students. His study yielded similar results to the previous studies whereby written feedback did have a significant positive effect on participants' writing achievements.

Briefly, the numerous number of studies conducted on corrective feedback have resulted in a variety of findings. The studies discussed in the previous section covered some of the findings of the last two decades. Some researchers (e.g. Alharbi, 2016; Ferris \& Roberts, 2001; Hashemnezhad \& Mohammadnejad, 2012; Khoshsima \& Ma'Farid, 2012) have established evidence in support of corrective feedback, arguing that it can help students improve their accuracy in writing.

\section{Studies on Grammatical Errors in Writing}

\section{The article system (definite and indefinite)}

According to Swan and Smith (2001:205), 'there is no indefinite article in Arabic, and the definite article has a range of use different from English'. Thomas (1989) demonstrated that learners of English do not necessarily have the equivalent of an article system, which means they encounter more problems when using articles. Interestingly, some studies (e.g. Heydari 2012; Karim \& Nassaji, 2013) suggested that mother tongue interference may be a reason for difficulties in learning a second language and in the acquisition of English articles. This interference is the influence of the native language on the learner's acquisition of the target language (Thyab, 2016). However, it is argued that English articles are one of the last grammatical features to be mastered. This is because the misuse of articles does not delay comprehension when language learners are speaking. Additionally, deciding which article to use or omit is confusing because it can only be sorted out in context (Master, 2002). Studies by (Bitchener, 2008; Bitchener \& Knoch, 2009; Sheen, 2007) have come to similar results, concluding that groups receiving any kind of corrective feedback did better using articles than those who had not. Bitchener (2008) also conducted a study on the efficiency of written corrective feedback in the English article system. The time frame was two months and the participants were 75 low intermediate ESL students at a New Zealand university. The researcher divided learners into four groups: those receiving direct corrective feedback and written metalinguistic explanation; those receiving direct corrective feedback only; and the control group, receiving no corrective feedback. All groups used three pieces of writing (pre-test, immediate post-test, and delayed post-test) and learners were asked to describe what was going on in a picture. The focus was on the use of the English article system (indefinite "a" and definite "the"). The researcher concluded that the accuracy of students receiving the written corrective feedback in the immediate post-test was better than those in 
the control group. Also, in the delayed post-test, the level of performance was still retained two months later.

Studies by Bitchener and Knoch (2009) and Sheen (2007) found similar results, with the experimental group performing better than the controlled group in the use of indefinite and definite English articles. Several researchers (e.g. Sheen, Wright \& Moldawa, 2009) yielded similar results showing that their ESL students had gained grammatical accuracy in writing over time.

\section{Prepositions in English}

Learning a new language and applying its rules is hard for many language learners. Many believe that they are confusing, with many rules to apply. In general, prepositions in English are not easy to teach or learn in EFL. Arab EFL learners do encounter special problems in learning English prepositions (Hajjaj, 1997). It is not an easy process, and according to Mahmoud (2011) there are about 124 prepositions in English, meaning that EFL learners take a while to learn them (Hendricks, 2010). Direct corrective feedback; however, can help with the misuse of prepositions or idiomatic lexis (Ferris, 2002).

Studies by (Alajmi, 2014; Bitchener, Young \& Cameron, 2005; Sawalmeh, 2013; Tahaineh, 2010; Chodorow, Gamon \& Tetreault, 2010) investigated the effect of written corrective feedback on the use of prepositions in English. A study by Alajmi (2014) was also conducted to examine the effective use of giving written corrective feedback to Arab speakers of English on ten uses of English prepositions. The researcher mentioned examples of preposition misuse, such as "married from," "die from," and "kind with."

For seven weeks, learners were divided into two groups: an experimental group and a control group. The former received general feedback whereas the latter received feedback that was more specific. The data was from three tests: pre-test, immediate post-test and delayed post-test as well as an open-ended questionnaire. The results showed that the experimental group outperforming the control group on the target features. The analysis of the questionnaire data also showed the usefulness of written corrective feedback for improving preposition use. The following study by Tahaineh (2010), encouraged giving written corrective feedback in writing. It was conducted on 162 high level university EFL students in Jordan, and aimed at finding the kind of errors they made when using prepositions in their essays. All students had similar educational backgrounds. The results showed that the mother tongue (Arabic) was affecting the student's choice of prepositions. If equivalents are not used in their mother tongue, students tend to choose the wrong preposition. So, students may use prepositions improperly even at advanced stages of their learning (Tahaineh, 2010). Moreover, a study by Sawalmeh (2013), in the Preparatory Year Program at Saudi university investigated errors in 32 essays. These secondary school graduates made several grammatical errors, including prepositions. The results suggested reducing these errors in Saudi students' essays by implementing some pedagogical implications which might assist EFL teachers in the future.
Chodorow et al. (2010) used two different machine based systems to identify and correct errors in English articles and prepositions. Both systems assisted EFL learners in using articles and prepositions, identifying errors and giving them suggestions for corrections. In both systems, the feedback given to students was useful, helping them to reduce errors in their final essays, as well as assisting them in becoming more selective regarding their choice of articles and prepositions.

\section{Studies on Lexical Errors in Writing}

Languages are built by words. They are useful and fundamental tools for communicating with others and acquiring knowledge. However, learning other languages is a challenge where one may encounter communication difficulties that lead to confusion since making mistakes when learning languages is inevitable. These lexical errors, which can in many cases cause miscommunication, are less tolerated by readers when compared to syntactic errors (Carter, 1998). Since the presence of lexical errors exist in second language learning, many studies have investigated linguistic errors committed by EFL learners. These have shown that EFL students do make both grammatical and lexical errors in writing (Al Karazoun, 2016). Through induction and analysis, some of these lexical errors have been identified as due to mother tongue interference and misunderstanding of the target language rules (Bao, 2015). Studies by (Hemchua \& Schmitt 2006; Zarei1 \& Rahnama 2013; Shalaby, Yahya \& El-Komi, 2009; Ferris \& Roberts, 2001) attempted to investigate various lexical errors in EFL writings. A study by Zareil, and Rahnama, (2013) investigated the effectiveness of corrective feedback on the accuracy of grammatical and lexical writing. It consisted of 164 participants divided into six groups who each received specified written corrective feedback. The participants were presented with a pre-test, a questionnaire, and a post-test. Three groups received written corrective feedback (the experimental groups) while the other three received nothing (the control groups). Regarding the results of lexical writing accuracy, the groups that received corrective feedback of some kind performed significantly better than the control group. Furthermore, Shalaby, Yahya, and El-Komi (2009) conducted a study at Taibah University examining the various types of lexical errors made by female foundation year students. The researchers collected 718 lexical errors from 96 writing samples.

The wrong choice of suffix was the highest category of errors, followed by direct translation from L1. In general, formal lexical errors were fewer than semantic lexical errors. Written corrective feedback may assist learners in improving accuracy in their writing when regular and frequent feedback is provided. Over time; however, it makes sense to reduce the amount of feedback and provide an opportunity for students to try to assess themselves (Freeman, 2004). To sum up, although little research has been conducted on lexical errors in EFL essays, the previous studies showed that written corrective feedback may help with students' lexical accuracy. 


\section{METHODS}

\section{Participants}

Participants in this study are foundation female students at the Health Studies Center, Prince Sultan Military Medical Center, Riyadh, Saudi Arabia. They enrolled in this program in the first semester of the academic year, taking four English skills separately as a part of the degree requirements for their diploma. The total number of students was 50 and divided into two groups: an experiment group $(n=29)$ and a control group $(n=21)$. Overall, the participants were similar in age, ranging between 19 to 20 years old. They had been taught English in public schools for almost seven years. According to the tests conducted at the beginning of the year by the center, the learners' English proficiency level ranged from low to pre-intermediate. These tests were not used as admission requirements, but only for diagnosing the students' level. In their foundation year, students receive 20 hours for learning English skills each week. The students are high school graduates, who will specialize in different medical majors, working in a hospital as nurses, technicians or doctors' assistants. For this reason, taking English courses is a requirement. According to the syllabus course description of writing, in the first semester, students learn to write short simple postcards or emails, fill in forms with their personal details and write simple isolated phrases and sentences. By the end of the foundation year, the aim of the course is for students to be proficient at a basic level corresponding to the CEFR level (Common European Framework of References). The English skills in the foundation year are more intensive than in the years that follow. Lastly, eight students were excluded from the study for two reasons. One was due to their absence in any one of the three tests. Another was because two students had written a short paragraph that they had memorized, while remaining unable to write about any of the six given topics.

\section{Instruments}

To gather the data for the current study, the students were given a writing test. Each student was given a pre-test, a post-test and a post-delayed test.

\section{The writing test}

Students in both the control group and the experimental group were given the writing test before and after the treatment (Appendix A). Students in both experimental and controlled groups were asked to write a short composition on one of the six given topics.

\section{The essay topics}

All students were asked to write a short essay after choosing one of the six topics, which were: why did you choose this field, the importance of technology in our lives, having only one language in the world, children and the media, controlling the Internet, or women at work.

\section{Essay grading}

The first researcher corrected and marked the three writing essays from all participants, making a total of 150 after the eight students who missed one of the three tests were excluded. Students were given two different marks; an overall general mark and a specific mark. As for the general mark, the grade points for each essay were allocated by an evaluation of traits; these were comprised of organization, mechanics, fluency, content and ideas.

The other mark was specifically assigned only for grammatical and lexical accuracy, with marks taken away with every grammatical or lexical error. The rater of the writing task, a native speaker, was an experienced EFL teaching staff member. The rating system was explained to the rater and some common rating problems were discussed.

\section{Procedure}

Participants were given forty-five minutes to write a short composition and told not to consult any electronic device or dictionary. Both groups, the control and the experimental, were first given pre-tests followed by post-tests in the same week. The period between the post-test and the post-delayed test was four weeks. All papers were corrected immediately. The experimental group received both written corrective feedback and individual oral feedback the day after the pre-test. Each student was called out individually by name outside her class, revised her mistakes with the first researcher and then received both written and oral feedback. However, students in the control group were not called out, did not see or revise their mistakes and received no feedback. In order to prevent the students from studying the feedback given to them earlier, the students were not told when the first researcher would be returning to the classroom.

\section{RESULTS AND DISCUSSION}

\section{Effect of Explicit Written Corrective Feedback on Students' Writing}

The first research question compares the usefulness of teacher's written corrective feedback for writing versus no feedback. The data were collected via a pre-test, treatment, post-test, and delayed post-test design for comparable groups. In order to recognize the influence of written corrective feedback for the students regarding their writing, the data were analyzed using an Independent Sample $t$-test as shown in Table 1:

Table 1 shows statistically significant differences between the female students' post-test scores for the two

Table 1. Post-test results of the t-test of both control and experimental groups

\begin{tabular}{lcccccc}
\hline Group & $\mathbf{n}$ & $\boldsymbol{M}$ & $\boldsymbol{S D}$ & $\boldsymbol{t}$ & $\boldsymbol{p}$ & Eta \\
\hline Control & 21 & 4.79 & 1.82 & -5.771 & 0.001 & 0.313 \\
Experimental & 29 & 7.83 & 1.85 & & & \\
\hline
\end{tabular}


experimental and control groups, in favor of the female students in the experimental group, with an average score of (7.83) compared to (4.79) for the control group. The previous results indicate that written corrective feedback did affect the writing skills of the foundation female students.

In order to identify the efficacy of corrective feedback in helping the female students improve their writing skills, a Paired Sample $t$-test was used to make a comparison between the female students' post-test scores and their results in the post-delayed test. This is clearly shown in Table 2:

As shown in Table 2, there are statistically significant differences between the female students' scores in the experimental group for both post and post-delayed tests. These were in favor of the students' post-test scores with an average of (7.83) compared to (6.55) for the students' post-delayed tests. The previous results reflected the inefficiency of corrective feedback for helping the female students retain their acquired writing skills.

Although the students' scores were lower in the post-delayed test than in the post-test, the average scores of the students in the experimental group were still higher than those of the students in the post-test control group, with a difference of (1.98). This reflects the efficacy of the test in improving the students' writing skills.

Table 2. $T$-test results showing differences between the students' experimental group in both post and post-delayed tests

\begin{tabular}{lccccc}
\hline Test & $\mathbf{n}$ & $\boldsymbol{M}$ & $\boldsymbol{S D}$ & $\boldsymbol{t}$ & $\boldsymbol{p}$ \\
\hline Post & 29 & 7.83 & 1.85 & 2.256 & 0.028 \\
Post-delayed & 29 & 6.55 & 2.42 & & \\
\hline
\end{tabular}

Second Question: To what extent does the use of written corrective feedback affect EFL students' written grammatical and lexical accuracy?

To determine the extent to which the use of written corrective feedback affected EFL students, regarding their ability to use grammar and vocabulary, an Independent Sample $t$-test was used, as shown in Table 3 :

For both experimental and control groups in the post-test groups, Table 3 shows statistically significant differences between the number of student errors regarding grammar. This is favor of the control group students, with an average number of errors amounting to (5.19) compared to (3.31) for the experimental group. The most prominent grammatical errors were the misuse of prepositions, nouns, verbs, the omission of articles, verbs, prepositions, and the addition of prepositions, nouns, verbs. The results above indicate that grammar-related errors by the post-test experimental group were fewer than those for the control group, reflecting the impact of written corrective feedback on increasing students' ability to use grammar correctly.

As shown in Table 3, there were statistically significant differences between the number of students' lexical errors in both the experimental and control post-test groups, favoring the control group, with the average number of errors amounting to (3.19), compared to (1.41) for the experimental group. The most common errors were spelling and direct translation from L1. The previous result indicated that the lexical errors of the experimental group were fewer than for those in the post-test control group, reflecting the impact of corrective feedback on improving students' vocabulary use.

To determine the effect of written corrective feedback on the students' accurate use of grammar and vocabulary, a Paired Sample $t$-test was used to compare the post-test results of the experimental group students, to those in the post-delayed test, as shown in Table 4:

Table 3. Post-test results for an Independent Sample $t$-test assessing differences for both control and experimental groups

\begin{tabular}{|c|c|c|c|c|c|c|c|}
\hline & Group & $\mathbf{n}$ & $M$ & $S D$ & $t$ & $p$ & Eta \\
\hline \multirow[t]{2}{*}{ Grammatical errors } & Control & 21 & 5.19 & 2.04 & 3.600 & 0.001 & 0.228 \\
\hline & Experimental & 29 & 3.31 & 1.65 & & & \\
\hline \multirow[t]{2}{*}{ Lexical errors } & Control & 21 & 3.19 & 2.60 & 2.846 & 0.008 & 0.152 \\
\hline & Experimental & 29 & 1.41 & 1.40 & & & \\
\hline \multirow[t]{2}{*}{ Total errors } & Control & 21 & 8.38 & 3.04 & 4.668 & 0.001 & 0.214 \\
\hline & Experimental & 29 & 4.72 & 2.49 & & & \\
\hline
\end{tabular}

Table 4. Independent Sample $t$-test results of differences in post-test and post-delayed test scores for the experimental group regarding the accurate use of grammar and vocabulary

\begin{tabular}{llllllr}
\hline & Test & $\mathbf{n}$ & $\boldsymbol{M}$ & $\boldsymbol{S D}$ & $\boldsymbol{t}$ & \multicolumn{1}{c}{$\boldsymbol{p}$} \\
\hline Grammatical & Post & 29 & 3.31 & 1.65 & 0.238 \\
mistakes & Post-delayed & 29 & 2.79 & 1.66 & & \\
Lexical mistakes & Post & 29 & 1.41 & 1.40 & -3.930 & 0.000 \\
& Post-delayed & 29 & 3.59 & 2.63 & & \\
Total mistakes & Post & 29 & 4.72 & 2.49 & -2.386 & 0.020 \\
& Post-delayed & 29 & 6.38 & 2.78 & & \\
& & & & & \\
\hline
\end{tabular}


Table 4 shows that regarding grammatical errors, no statistically significant differences between the errors of the experimental group students either in the post or the post-delayed tests were found, with an average number of errors amounting to (3.31) for the post-test and (2.79) for the post-delayed test. The significance level value was $(0.238)$, which is more than $(0.05)$, indicating that this is not statistically significant. The previous results indicated that written corrective feedback did influence the foundation female students' accurate use of grammar.

The results in Table 4 indicated that there were statistically significant differences for vocabulary used by the students in the experimental group, both in the post-test and the post-delayed test. The total score for errors, favoring the post-delayed test, had students with average errors of (3.59) compared to (1.41) for the post-delayed test regarding lexical errors and (6.38) compared to (4.72) for students in the post-test in relation to the overall degree of errors. The previous results indicated that written corrective feedback has little impact on the students' lexical accuracy, as well as on lexical and grammatical accuracy combined. Although there were statistically significant differences for the total score of errors in the post-test and post-delayed test, the overall error score for post-delayed test was lower than for the post-test in the control group, averaging (8.38) errors in the control group and (6.38) in the post-delayed. In other words, written corrective feedback still had an impact on students' grammar and vocabulary accuracy.

The study also found that corrective written feedback had an effect on increasing the female students' ability to develop their writing skills. This is consistent with the findings of other studies indicating that written corrective feedback can help improve learners' writing skills and their writing accuracy (e.g. Ferris, 2004; Ferris \& Roberts, 2001; Hyland \& Hyland, 2006; John et al., 2005; Chandler, 2003; Bitchener \& Knoch, 2010b; Bitchener, 2012; Khoshsima \& Ma'Farid, 2012; Hashemnezhad \& Mohammadnejad, 2012; Ferris \& Roberts, 2001; Alharbi, 2016). This contradicts (Doff, 1988; Truscott, 1996) and others who claim that corrective feedback is not worthwhile.

Furthermore, the results showed that grammatical and lexical errors made by the students of the experimental group were fewer than those made by the control group in the posttest. This is consistent with the findings of other studies indicating that written corrective feedback is effective for the use of articles in English (e.g. Bitchener, 2008; Bitchener \& Knoch, 2009; Sheen, 2007), and the use of prepositions (e.g. Alajmi, 2014; Bitchener, Young \& Cameron, 2005; Sawalmeh, 2013; Tahaineh, 2010; Chodorow et al., 2010). This demonstrates that EFL learners may gain grammatical accuracy in writing over time, which is consistent with the findings of researchers like (Sheen, Wright \& Moldawa, 2009). Although, according to the results, corrective feedback had little impact on lexical accuracy, researchers (e.g. Hemchua \& Schmitt 2006; Zarei1 \& Rahnama 2013; Shalaby, Yahya, \& El-Komi 2009; Ferris \& Roberts 2001) found that, over time, written corrective feedback may decrease the various lexical errors found in EFL writing and increase accuracy. Thus, the previous conclusion indicates that written corrective feedback influences students' ability to develop their writing skills, which differs from a number of studies reviewed earlier.

\section{Examples of errors found in the experimental group}

The following examples illustrate a number of different errors made by many of the learners in the experimental group, both before and after the provision of written corrective feedback.

Example 1: Error type: grammatical: addition of article/lexical: spelling

Pre-test: Language is *importintat to *the *pepole to *comenicate with *each others.

Post-test: Language is important to people to communicate with each other.

Post-delayed test: The most beautiful thing in people is ...

After the pre-test, the student received feedback regarding the addition of the article-the, in the people and the addition of double marking of the morpheme-s in each others This student was given both oral and written corrective feedback. She made use of the feedback in the post-test, which took place a day after the pre-test, and was able to retain this feedback even four weeks' later in the post-delayed test where she did not insert articles randomly and wrote people correctly.

Example 2: Error type: grammatical: omission of preposition and misordering

Pre-test: I *want talk about *language English. *Becus the *languase *beatiful.

Post-test: I want to talk about English language. English is a beautiful language.

Post-delayed test: I want to talk about having one language in the world, it's English language. Because English is a beautiful language.

The student omitted the infinitive -to and had written language English in the wrong order. After receiving oral and written feedback in both the post-test and the post-delayed test, the student was able to make use of and recall the feedback given, correctly inserting the infinitive -to and avoiding the misordering of the previous words. Also, the spelling errors in the pre-test (becus, languase, beatiful) changed after feedback was given. In the post-delayed test, the student was able to remember the correct spellings.

Example 3: Error type: Misuse of pronoun and misordering. Lexical: L1 interference

Pre-test: All parents give *your children mobiles. I hope parents don't give *your children phones, give them games useful. The phones *doesn't learn correctly. Post-test: I hope parents don't give their children phones, give them useful games. They (referring to phones) teach un-useful things.

Post-delayed test: The parents gives their children mobiles. I would like to give you advice, don't give their children mobile before ten years.

As can be noticed, the student in the pre-test used an incorrect pronoun in two of the sentences, she wrote games useful in the wrong order and chose learn instead of teach due to first language interference. After receiving written corrective feedback, the student was able to avoid the pre- 
vious errors in the post-test. She used the correct pronouns, avoided misordering words and made the right choice of the word teach according to its contextual meaning. However, four weeks later, in the post-delayed test, she failed to retain the written corrective feedback and made the same errors again. The effect of feedback for this student was weak, most likely because it was given just once and not received as a constant feedback.

Example 4: Error type: addition of article - the/a, and morphemes

Pre-test: We *used *a smart *phone, tablets, *computer, social media. The technology is everywhere.

Post-test: We use smart phones, tablets, computers, and social media. Technology is important.

Post-delayed test: The technology help the world. It is give everything do you want.

The feedback was effective in the post-test where the student used articles properly. Moreover, the student added the plural -s correctly as she was told to do in the feedback. However, the feedback was not recalled at the time of the post-delayed test, where the student added the article - the, omitted the morpheme $-s$, and double marked the sentence with the verbs - is and give. This might have been due to the length of time that elapsed between the two tests and because she received feedback only once.

\section{Examples of Errors Found in the Control Group}

The following examples illustrate the different errors made by many learners in the control group, where feedback was not provided. The students differed in both their level of writing and their scores; however, the errors made by many of the students ( 17 students) in this group were repeated in all tests. It was thought that feedback could have helped bring their attention to these errors, aid in processing them and then be assistive in the recall of information, as many of their peers in the experimental group could do.

Example 1: Error type: grammatical: addition of articles. lexical: spelling

Pre-test: *The life is gonna be *eazy with technology.

Post-test: Technology make *eazy *lilfe, it is smart in *the life.

Post-delayed test: The technology is very important in our live.

The student used the article -the incorrectly in all three tests and made the same spelling mistake eazy along with other misspelled words repeatedly in each test as well.

Example 2: Error type: grammatical: sentence structure and lexical: spelling

Pre-test: My *dreem a nurse *becus I like to help me.

Post-test: I am is *dreem work the *hosbetal.

Post-delayed test: I love with good *pebole *dreem at working.

This student made the same number of errors in all three tests, amounting to 13 different errors. Most were grammatical and related to sentence structure, as well as spelling errors. Almost all the sentences were hard to understand due to the structure. Although this student had very poor English skills, written corrective feedback could help guide her, even if processing it could take some time.
Example 3: Error type: grammatical: addition

Pre-test: *Nowadays, we can't live without technology.

*Technology it is so important in our life.

Post-test: What is technology? *Technology it is something important in our life we can't live without technology. Everybody use the technology *in nowadays

Post-delayed test: No one can live without technology *in nowadays. *Technology it is so important in our life all ages use technology.

Although this student used nowadays correctly in the pretest, she added the preposition -in with nowadays in both the post-test and the post-delayed test. It was believed that feedback would have helped her realize that it was correct the first time. Also, the student repeated the same pattern in many sentences throughout the three tests, where she added a pronoun after the subject of a sentence (it). With immediate feedback, this might have been resolved.

Example 4: Error type: grammatical: misuse of pronoun

Pre-test: They can also search about *them homework and internet help *thim.

Post-test: You must see what *them watch and see what *them search it about.

Post-delayed test: Parents and family should see what *thim search and see *midea.

This student used the object pronoun -them incorrectly in all three tests, indicating a misunderstanding of the use of pronouns, a common problem for beginner EFL learners. Feedback may help draw the student's attention to this repeated error and help resolve this grammatical uncertainty.

To sum up, in the previous examples, students omitted or added one or more articles. This corroborates with several studies mentioned earlier that indicated the difficulty of choosing which article to use and mastering the article system (Master, 2002). Moreover, according to the results above, students in the experimental group had fewer errors in their post-tests than students in the control group. This indicates that written corrective feedback did have an effect on reducing the number of errors, thus helping to produce a better piece of writing (Bitchener, 2008; Bitchener \& Knoch, 2009; Sheen, 2007). As for errors with prepositions, students also made errors by selecting the wrong preposition or omitting it. According to the results, corrective feedback helped learners avoid some errors in the post-test, and this is similar to some of the study results mentioned earlier (Bitchener, Young \& Cameron, 2005). Although it has been assumed by many EFL teachers that written corrective feedback helps students improve the accuracy of their writing over time, more studies need to be conducted into how and when to give feedback, the factors that contribute to the efficiency of corrective feedback and the factors that leave a negative impression.

\section{CONCLUSION}

The present study examined the effect of teachers' written corrective feedback for female foundation students' writing achievements in an EFL Saudi context. Based on the findings, teachers' written corrective feedback had a significantly 
positive effect on students' writing achievements and helped improve learners' skills. It also showed that grammatical and lexical accuracy can be improved through the constant giving of written corrective feedback. The study has offered positive support for the practice of written corrective feedback and added to the growing body of evidence investigating and indicating the influence of teachers' written corrective feedback on improving EFL learners' writing achievements and producing fewer errors. Teachers need to think of feedback as a vital contribution to learning and an important way for learners to reflect upon their own work. For learning to be more effective and produce more confident writers, teachers may consider the power and effectiveness of immediate well-given feedback.

\section{REFERENCES}

Alajmi, A. (2014). The effect of written corrective feedback on Omani students' accuracy in the use of English prepositions. Advances in Language and Literary Studies, $6(1), 1-11$.

Alharbi, S. (2016). Effect of teachers' written corrective feedback on Saudi EFL university students' writing achievements. International Journal of Linguistics, $8(5), 15-29$.

Al-Hazmi, S. (2006). Writing Reflection: Perceptions of Arab EFL Learners. South Asian Language Review, XVI (2), 36-52.

Al Karazoun, G. (2016). A linguistic analysis on errors committed by Jordanian EFL undergraduate students: a case of news headlines in Jordanian newspapers. English Language Teaching, 9(8), 170-189.

Alsamdani, H.A. (2010). The relationship between Saudi EFL students' writing competence, L1 writing proficiency, and self-regulation. European Journal of Social Sciences, 16(1), 53-63.

Bao, X. L. (2015). Analysis on lexical errors in college English writing. Canadian Social Science, 11(12), 127-130.

Bitchener, J. (2008). Evidence in support of written CF. Journal of Second Language Writing, 17(2), 102-118.

Bitchener, J., \& Ferris, D. (2012). Written Corrective Feedback in Second Language Acquisition and Writing. New York: Routledge.

Bitchener, J., \& Knoch, U. (2010a). The contribution of written corrective feedback to language development: A ten-month investigation. Applied Linguistics, 31(2), 193-214.

Bitchener, J., \& Knoch, U. (2010b). Raising the linguistic accuracy level of advanced L2 writers with written CF. Journal of Second Language Writing, 19(4), 207-217.

Bitchener, J., \& Knoch, U. (2009). The relative effectiveness of different types of direct written corrective feedback. System, 37(2), 322-329.

Bichener, J., \& Storch, N. (2016). Written corrective feedback for L2 development. Bristol, Buffalo, Multilingual Matters.

Bitchener, J., Young, S., \& Cameron, D. (2005). The effect of different types of corrective feedback on ESL student writing. Journal of Second Language Writing, 14(3), 191-205.
Candling, R. (2001). Vocabulary and language teaching. New York: Longman Inc.

Carter, R. (1998). Vocabulary: Applied linguistics perspectives. London: Routledge.

Chandler, J. (2003). The efficacy of various kinds of error feedback for improvement in the accuracy and fluency of 12 student writing. Journal of Second Language Writing, 12(3), 267-296.

Chodorow, M., Gamon, M., \& Tetreault, J. (2010). The utility of article and preposition error correction systems for English language learners: feedback and assessment. Language Testing, 27(3), 419 - 436.

Doff, A. (1988). Teach English: A training course for teachers. Cambridge: Cambridge University Press.

Ferris, D. R. (2007). Preparing teachers to respond to student writing. Journal of Second Language Writing, 16(3), $165-193$.

Ferris, D. R. (2004). The "grammar correction" debate in L2 writing: Where are we, and where do we go from here? (and what do we do in the meantime?). Journal of Second Language Writing, 13(1), 49-62.

Ferris, D. R. (1999). The case for grammar correction in L2 writing classes: A response to Truscott (1996). Journal of Second Language Writing, 8(1), 1-10.

Ferris, D. R. (2003). Response to student writing: Implications for second language students. Mahwah, NJ: Lawrence Erlbaum Associates.

Ferris, D. R. (2002). Treatment of error in second language writing. Michigan: The University of Michigan Press.

Ferris, D., \& Roberts, B. (2001). Error feedback in L2 writing classes: How explicit does it need to be? Journal of Second Language Writing, 10(3), 161-84.

Freeman, R. Lewis, R. (2004). Planning and Implementing Assessment. London: Kogan Page.

Hashemnezhad, H., \& Mohammadnejad, S. (2012). A case for direct and indirect feedback: The other side of coin. English Language Teaching, 5(3), 1-10.

Hemchua, S., \& Schmitt, N. (2006). An analysis of lexical errors in the English compositions of Thai learners. Prospect, 21(3), 3-25.

Hendricks, M. (2010). Consciousness-raising and prepositions. English Teaching Forum, 48(2), 24-29.

Heydari, P. (2012). Error analysis: Sources of L2 learners' errors. Theory and Practice in Language Studies, 2(8), 1583-1589.

Hyland, K., \& Hyland, F. (2006). Feedback on second language students' writing. Language Teaching, 39(2), 83-101.

Karim, K., \& Nassaji, H. (2013). First language transfer in second language writing: an examination of current research. Iranian Journals of Language Teaching Research, 1(1), 117- 134.

Kharma, N. and Hajjaj, A. (1997). Errors in English among Arabic speakers. Beirut: Librairie du Liban.

Khoshsima, H., \& Farid, M. J. (2012). The long-term effect of implicit and explicit corrective feedback on accuracy of EFL learners' descriptive writing skill. Iranian Journal of Applied Language Studies, 4(2), 119-134. 
Mahmoud, A. (2011). The use of prepositions by Arab EFL learners: Looking on the bright side. The Buckingham Journal of Language and Linguistics, 4, 84-90.

Master, P. (2002). Information structure and English article pedagogy. System, 30(3), 331-348.

Sawalmeh, M. (2013). Error analysis of written English essays: The case of students of the preparatory year program in Saudi Arabia. English for Specific Purposes World, 14(40), 1-17.

Shalaby, N., Yahya, N., \& El-Komi, M. (2009). Analysis of lexical errors in Saudi college students' compositions. Journal of the Saudi Association of Languages and Translation, 2(3), 65-92.

Sheen, Y. (2007). The effect of focused written corrective feedback and language aptitude on ESL learners' acquisition of articles. TESOL Quarterly, 41 (2), 255-283.

Sheen, Y., Wright, D., \& Moldawa, A. (2009). Differential effects of focused and unfocused written correction on the accurate use of grammatical forms by adult ESL learners. System, 37(4), 556-569.

Swan, M., \& Smith, B. (2001). Learner English: A teacher's guide to interference and other problems. Cambridge, University Press.

Tahaineh, Y. (2010). Arab EFL university students' errors in the use of prepositions. The utility of article and prep- osition error correction systems for English language learners: Feedback and assessment. Modern Journal of Applied Linguistics, 1(6), 76-112.

Thomas, M. (1989). The acquisition of English articles by first- and second-language learners. Applied Psycholinguistics, 10(3), 335-355.

Thyab, R. (2016). Mother-tongue interference in the acquisition of English articles by L1 Arabic students. Journal of Education and Practice, 7(3), 1-4.

Truscott, J. (2007). The effect of error correction on learners' ability to write accurately. Journal of Second Language Writing, 16(4) 255-272.

Truscott, J. (1996). The case against grammar correction in L2 writing classes. Language Learning, 46(2), 327-369.

Ur, P. (1996). A Course in Language Teaching: Practice and Theory. New York: Cambridge University Press.

Williams, J., \& Jasmine, G. (2003). Providing feedback on ESL students' written assignments. TESL-EJ, 10(4), 1-6.

Zareil, A., \& Rahnama, M. (2013). The effect of written corrective feedback modes on EFL learners' grammatical and lexical writing accuracy: from perceptions to facts. International Journal on Studies in English Language and Literature, 1(3), 1-14.

\section{APPENDIX A. THE WRITING TEST}

Name Group

Write an essay about ONE of the following topics:

1. Why you chose this field.

2. The importance of technology in our lives.

3. Having ONE language in the world.

4. Children and the media.

5. Controlling the internet.

6. Women in work. 